\title{
Sistem Pakar Buta Warna Menggunakan Bangun Ruang Berbasis Mobile Dengan Sistem Operasi Android
}

\author{
(Blind Color Expert System Using 2D Shape Based On Android Operating System)
}

\author{
I Wayan Putu Sarwe Windusara, Ario Yudo Husodo, Ariyan Zubaidi \\ Program Studi teknik Informatika, Fakultas Teknik, Universitas Mataram \\ Jl. Majapahit 62, Mataram, Lombok NTB, INDONESIA \\ Email: putusarwe@gmail.com, ario@ti.ftunram.ac.id, zubaidi13@unram.ac.id
}

\begin{abstract}
Color blindness is one of the eye diseases that attack the eye's conical cells which cannot see several colors. One way to detect color blindness is using the Ishihara Test. This test uses images that have any colors that can outwit people with color blindness. Ishihara test uses a number that can't be read by some people so that new images is made of 2D shape to replace the number that will be combined with the expert system to provide an initial diagnosis according to the expert. The expert system is developed on a mobile device with the Android operating system. There are several tests on the subject of partial color blindness and subject with a normal eye, with the result of Ishihara's Test can reach $100 \%$ accuracy with a time limit of only 15 seconds. Therefore, this system has the fit of workflow and conclusion with the Ishihara Test.
\end{abstract}

Key words: Color Blind, Ishihara Test, 2D Shape, Expert systems, android.

\section{Pendahuluan}

Dalam kehidupan sehari-hari, mata adalah salah satu indra yang sangat berguna bagi kehidupan manusia. Mata dapat membuat manusia melihat keadaan di sekitar kita dengan jelas dan berwarna. Akan tetapi tidak dapat disanggah bahwa semakin banyak masyarakat yang fungsi kerja matanya terganggu, bisa dikarenakan kegiatan yang membebani mata ataupun gangguan keturunan. Salah satu gangguan mata adalah buta warna. Buta warna adalah penglihatan warna-warna yang tidak sempurna, buta warna juga dapat diartikan sebagai suatu kelainan penglihatan yang disebabkan ketidakmampuan sel-sel kerucut (cone cell) pada retina mata untuk menangkap suatu spektrum warna tertentu sehingga objek yang terlihat bukan warna yang sesungguhnya [1]. Sebagian besar kasus buta warna ditemukan pada kaum pria, dengan persentase mencapai 7$10 \%$, sementara pada wanita yang ditemukan kurang dari $1 \%$ [2].

Tes yang digunakan untuk menguji seseorang mengalami gangguan buta warna biasanya adalah tes Ishihara, yang kebanyakan menggunakan perbandingan warna dengan memainkan angka yang memiliki warna menyerupai background angka [3]. Dalam buku tes
Ishihara belum terdapat gambar tes dalam bentuk bangun ruang, sehingga dengan membuat plat dalam bentuk bangun ruang akan menambah plat-plat dalam mendeteksi kebutaan terhadap warna bagi masyarakat yang belum dapat memahami angka atau yang masih belum mengerti angka. Sehingga mendeteksi kebutaan terhadap warna bagi masyarakat sangat penting termasuk kepada masyarakat yang belum memahami angka dimana akan dapat membantu memberikan saran mengenai segala hal yang berkaitan dengan masalah buta warna.

Sistem pakar adalah sistem yang mengadopsi pengetahuan manusia ke dalam komputer, sehingga komputer dapat digunakan untuk menyelesaikan suatu masalah sebagaimana yang dilakukan oleh seorang pakar [4]. Sistem pakar dewasa ini tidak hanya dapat dibuat pada perangkat komputer namun sudah dapat diimplementasikan di berbagai perangkat lainnya seperti perangkat mobile. Hasil survey [8] pada tahun 2016, sebagian besar masyarakat di indonesia memiliki handphone, sekitar 47,6\% atau setara 63,1 juta jiwa menggunakan smartphone untuk mengakses internet. Aplikasi mobile memiliki beragam sistem operasi seperti android, ios, microsoft, symbian dan lainnya. Pengguna aplikasi mobile lebih banyak menggunakan sistem operasi android, seperti di lansir badan statistik dunia bahwa persentase pengguna sistem operasi android sekitar $82,8 \%$ pada tahun 2016 mengalahkan pesaing lainnya. Sehingga dengan mengembangkan sebuah sistem pakar berbasis mobile dengan sistem operasi android akan dapat digunakan oleh masyarakat.

Berdasarkan latar belakang yang telah dijelaskan maka akan dikembangkan sebuah penelitian yang berjudul sistem pakar pendeteksi buta warna menggunakan gambar bangun ruang berbasis mobile dengan sistem operasi android. Judul tersebut dikembangkan agar dapat membantu masyarakat dalam mendeteksi buta warna baik yang memahami angka maupun masyarakat yang belum memahami angka sehingga bermanfaat untuk berbagai hal dikemudian hari. 


\section{TINJAUAN PUSTAKA}

Pada penelitian [5], dilakukan peneliti menggunakan plat Ishihara dengan metode forward chaining dan menggunakan metode one feature sebagai bahan uji validasi. Keunggulan berdasarkan penelitian dan pengembangan aplikasi yang telah dilakukan adalah mampu menghasilkan alat bantu diagnosa buta warna secara valid menggunakan smartphone android karena aplikasi ini mampu memberikan akurasi 90\% yang diuji cobakan kepada 22 pengguna dan dapat diaplikasikan pada android minimal versi API level 14. Dalam penelitian tersebut juga terdapat beberapa saran, dalam pengembangannya dapat menggunakan metode lain serta menggunakan database offline dengan soal-soal tes diacak dan memberikan pemeriksaan validasi dari pakar lebih sempurna.

Pada penelitian [6], dibuat program sistem pakar dengan metode penalaran maju yang telah dapat menjadi alat bantu dalam pemeriksaan buta warna karena telah memberikan hasil yang sesuai dengan pemeriksaan secara manual dan dapat menggantikan peran seorang pakar. Namun masih terdapat beberapa pengembangan yang diperlukan seperti penggunaan database lain yang memiliki kemampuan lebih agar dapat menyimpan basis pengetahuan yang selalu berubah serta perlu disediakan fasilitas keamanan data dan program agar tidak dapat manipulasi.

Sedangkan pada penelitian [7] telah dapat menghasilkan sistem pakar yang dapat mengetahui jenis buta warna, keterangan tentang buta warna serta perbandingan jawaban yang dianggap benar dan alam penelitian terkait menggunakan metode Ishihara. Sistem yang dibangun telah dapat mengetahui apakah pengguna mengidap buta warna atau tidak, dapat mengetahui jenis buta warna parsial, keterangan tentang buta warna dan perbandingan jawaban yang dianggap benar. Aplikasi dapat juga dikembangkan dengan membuat aplikasi lebih akurat, penambahan metode-metode lainnya dan memperindah tampilan.

\section{MEtode USULAN}

Secara umum perancangan sistem pakar terdiri atas User, Knowledge Base, Inference Engine dan Output dapat dilihat pada Gambar 1.

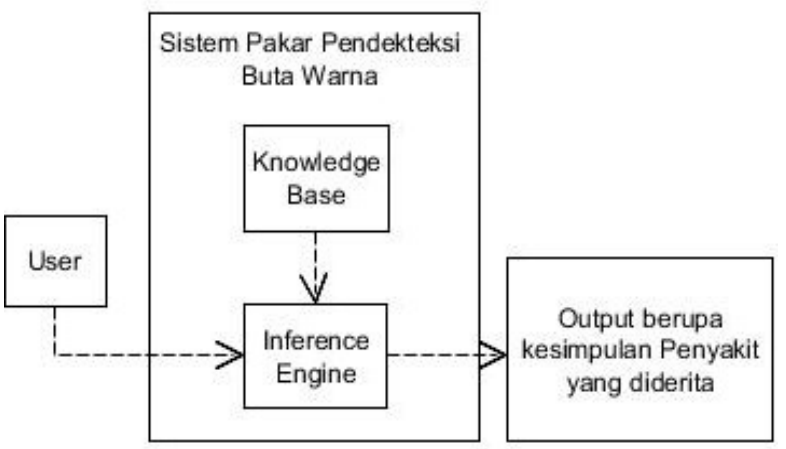

Gambar 1. Blok Diagram Sistem Pakar Penyakit Mata
User dalam sistem pakar adalah pengguna aplikasi yang akan dibuat, dalam penelitian ini adalah masyarakat secara umum. Knowledge Base berisi kumpulan dari faktafakta mengenai situasi, kondisi atau permasalahan yang ada dan aturan-aturan yang digunakan sebagai acuan dalam menggunakan pengetahuan untuk menyelesaikan masalah yang ada. Dalam sistem yang akan dibangun digunakan metode Ishihara sebagai role dalam menentukan hasil dari sistem, metode Ishihara menggunakan gambar-gambar dengan bentuk angka yang dapat mengecoh penderita buta warna dengan beragam gradasi warna. Dalam penelitian ini gambar angka yang digunakan Ishihara akan digantikan dengan gambar bangun ruang seperti terdapat pada Gambar 2 sampai Gambar 15 berikut.

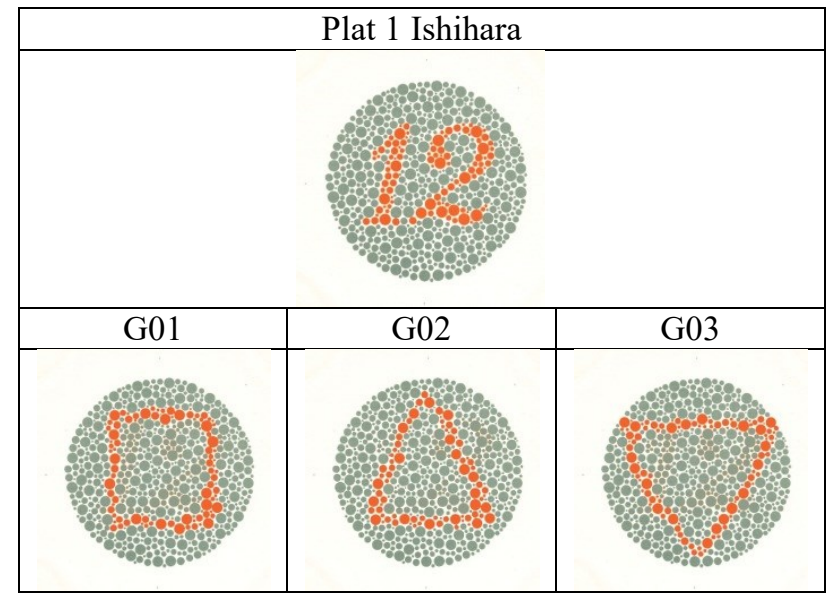

Gambar 2. Perubahan Plat 1 pada Metode Ishihara

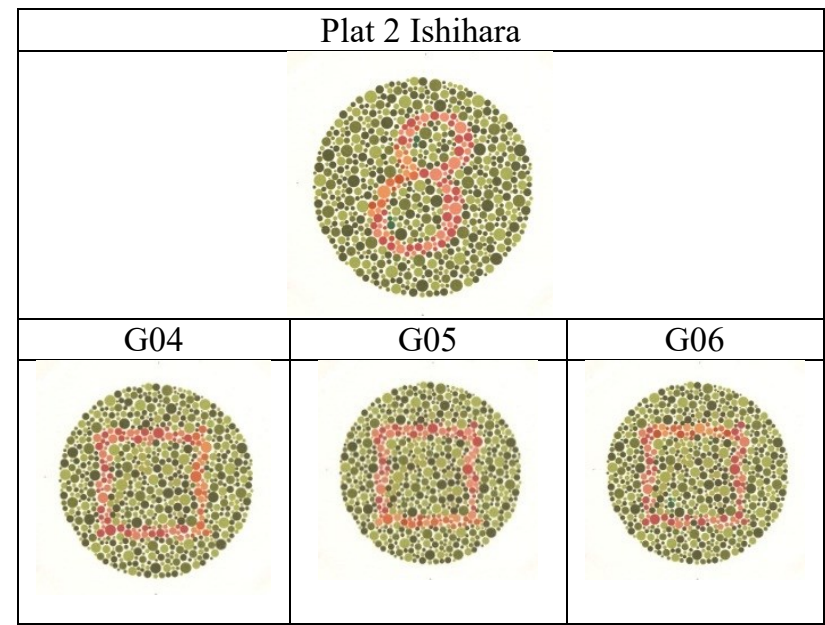

Gambar 3. Perubahan Plat 1 pada Metode Ishihara 


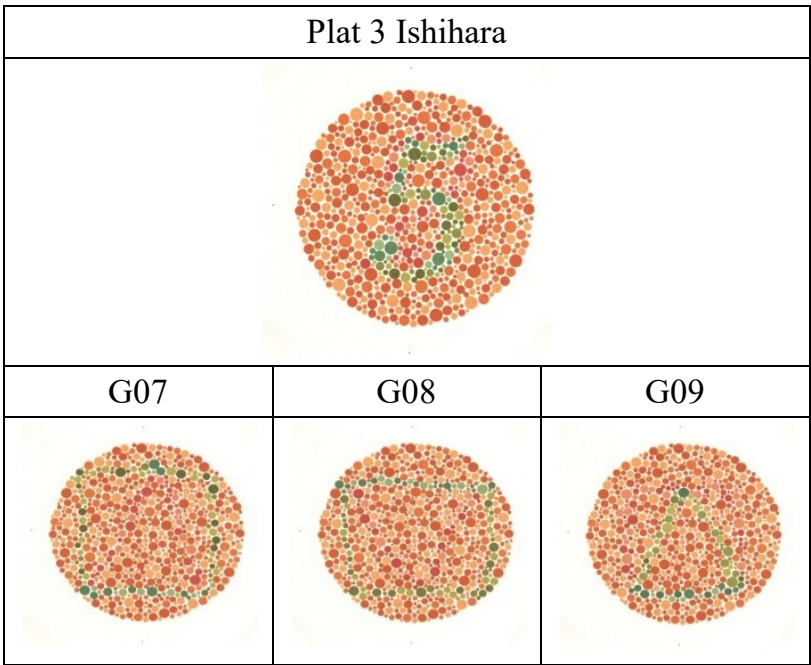

Gambar 4. Perubahan Plat 3 pada Metode Ishihara

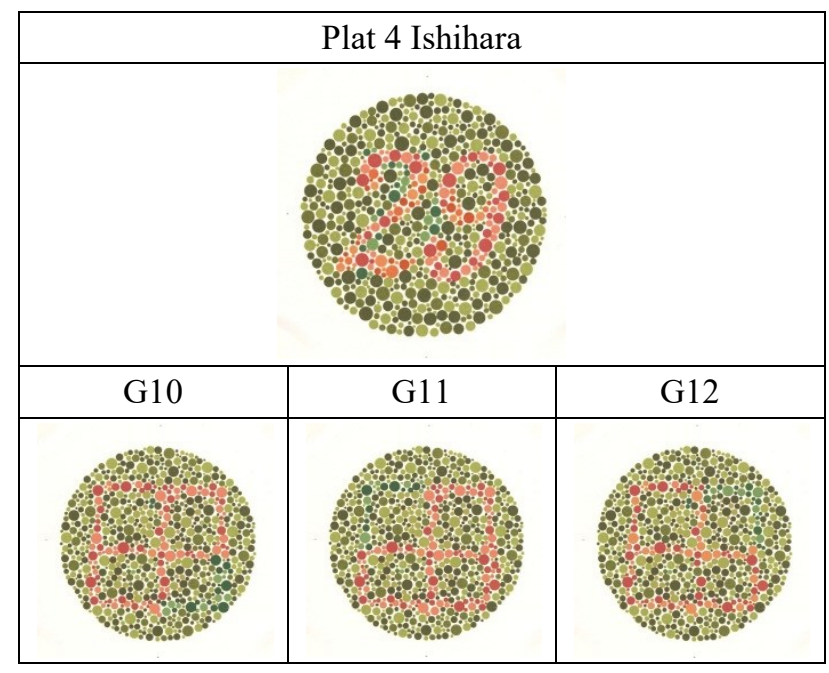

Gambar 5. Perubahan Plat 4 pada Metode Ishihara

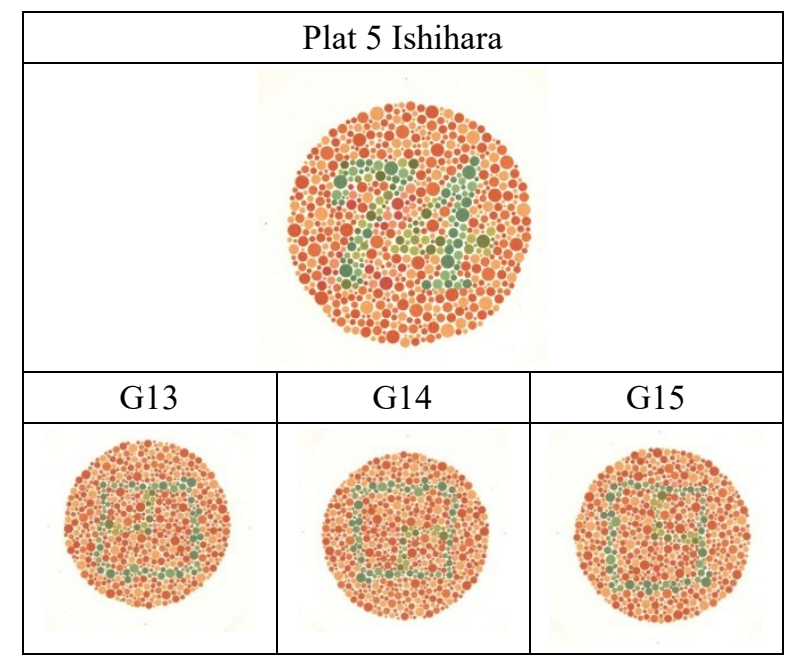

Gambar 6. Perubahan Plat 5 pada Metode Ishihara

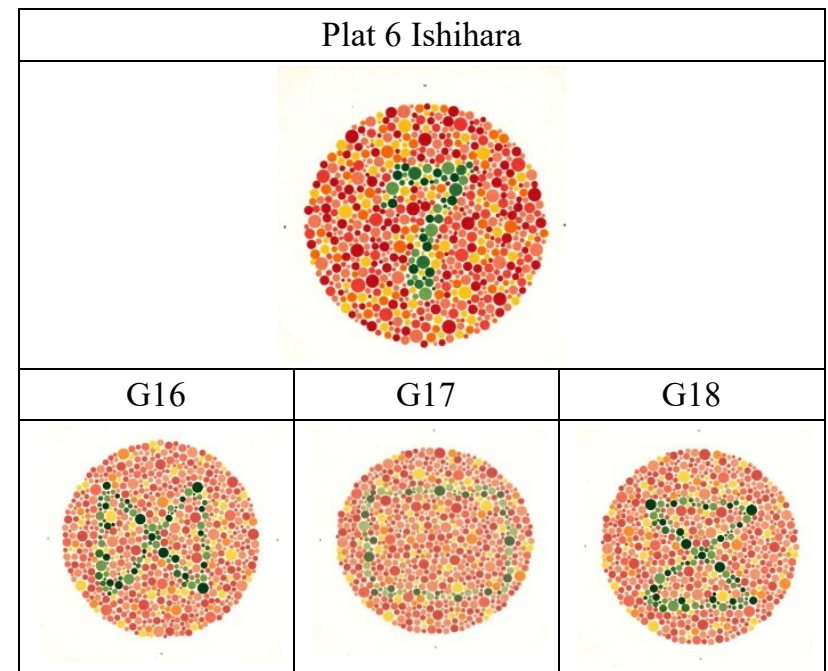

Gambar 7. Perubahan Plat 6 pada Metode Ishihara

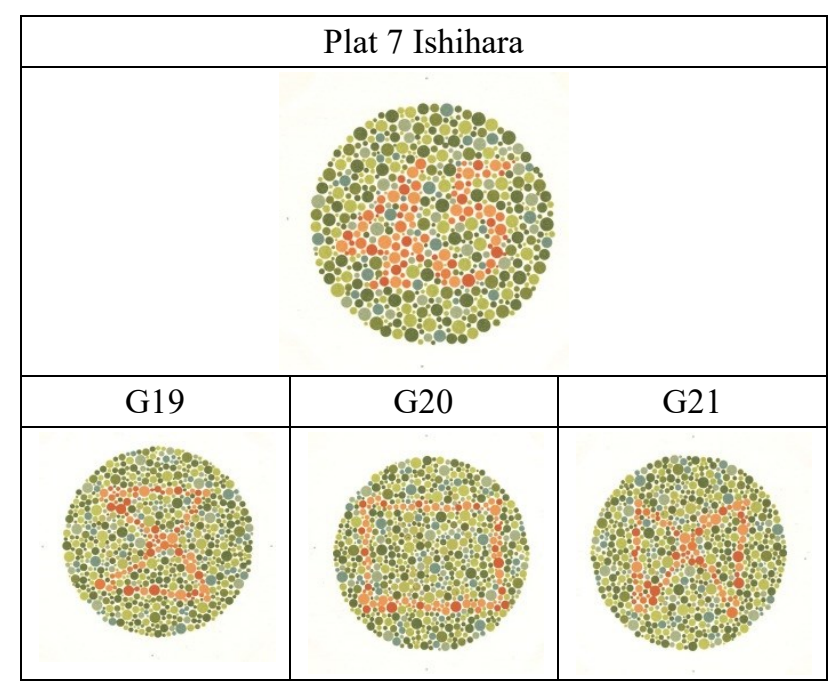

Gambar 8. Perubahan Plat 7 pada Metode Ishihara

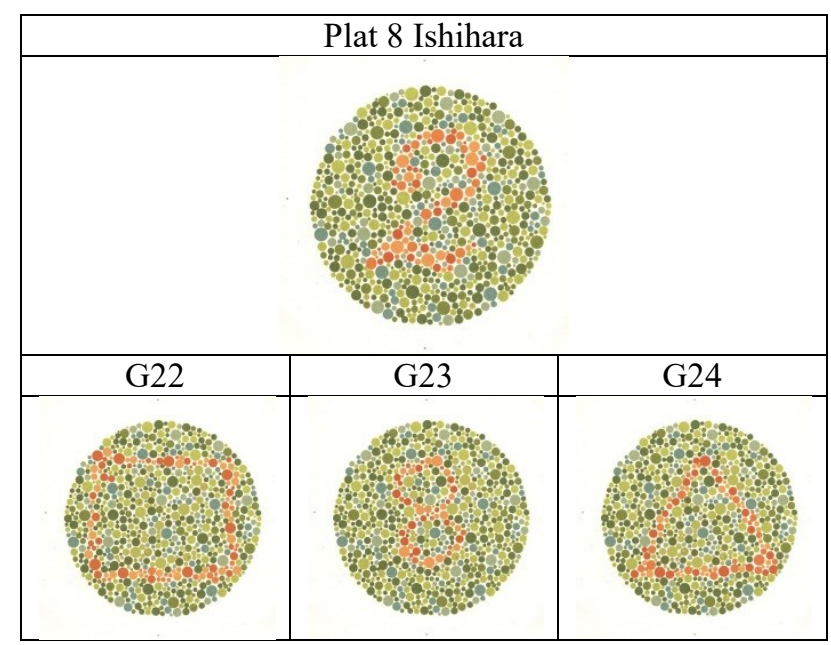

Gambar 9. Perubahan Plat 8 pada Metode Ishihara 


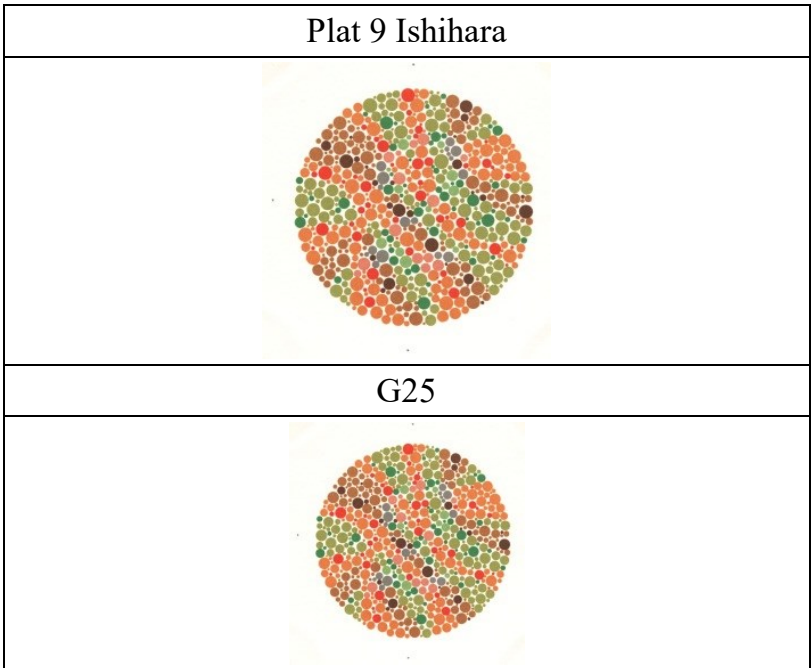

Gambar 10. Perubahan Plat 9 pada Metode Ishihara

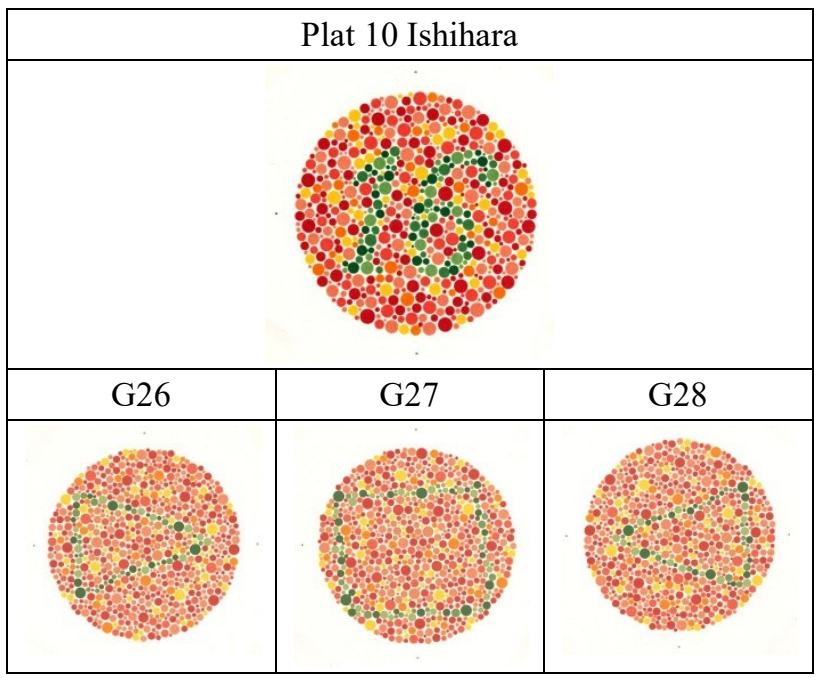

Gambar 11. Perubahan Plat 10 pada Metode Ishihara

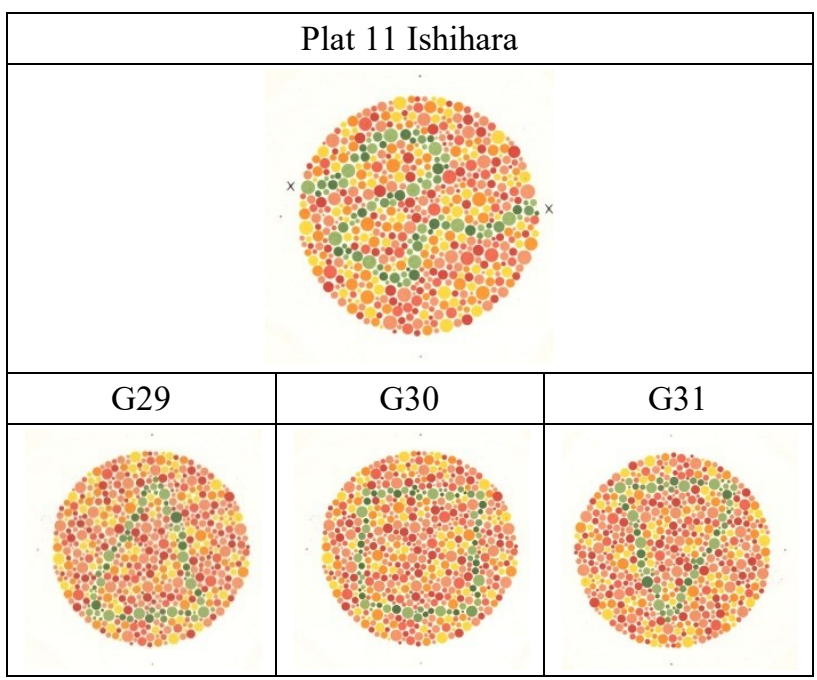

Gambar 12. Perubahan Plat 1 pada Metode Ishihara

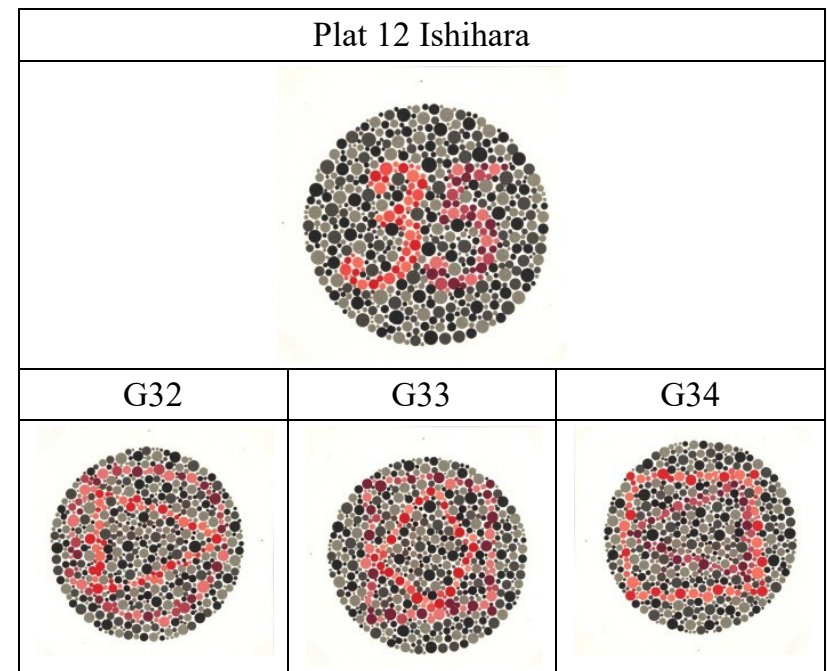

Gambar 13. Perubahan Plat 12 pada Metode Ishihara

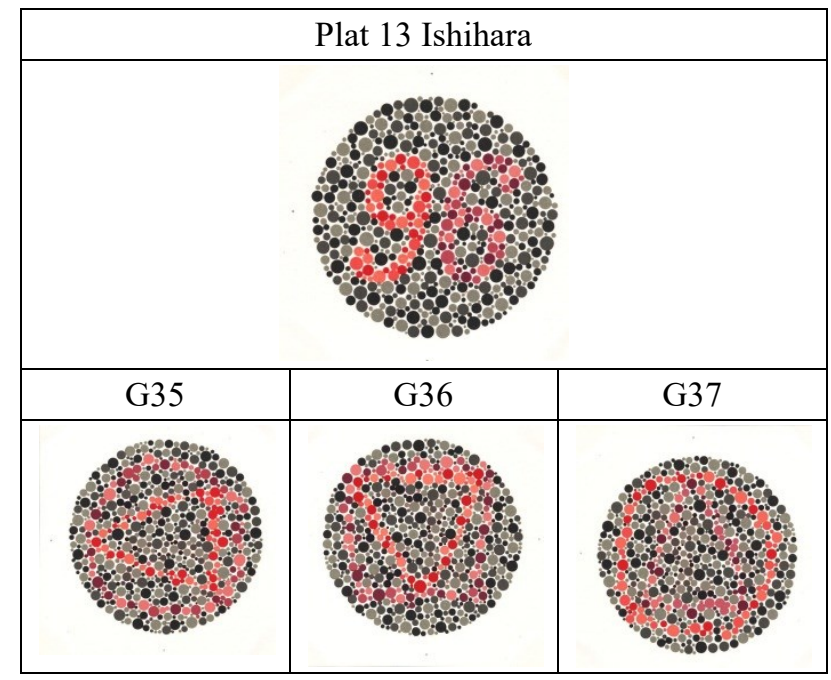

Gambar 14. Perubahan Plat 13 pada Metode Ishihara

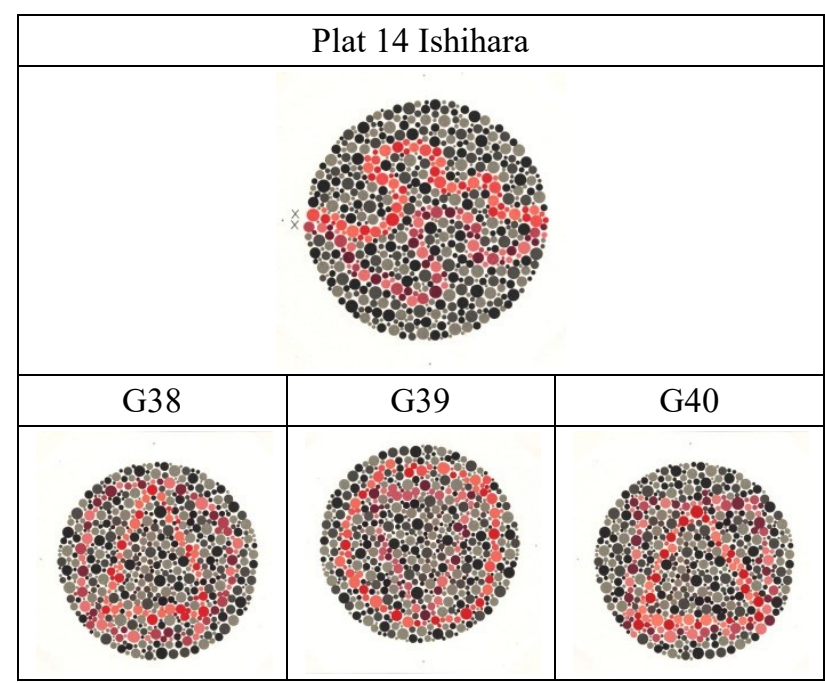

Gambar 15. Perubahan Plat 14 pada Metode Ishihara 
Inference Engine sebagai aplikasi yang akan memandu proses penalaran terhadap suatu kondisi berdasarkan pada basis pengetahuan yang ada, memanipulasi, mengarahkan rule, model dan fakta yang disimpan pada Knowledge Base untuk mencapai sebuah kesimpulan. Proses mesin infereni ii tergambar pada Gambar 16, dimulai dengan menjawab plat 1 yang menjadi aturan pertama. Jika tidak dapat menjawab plat pertama maka tidak dapat melanjutkan tes, jika berhasil menjawab maka akan berlanjut pada plat 2 hingga plat 14 dengan kesimpulan yang akan diproses ketika telah menyelesaikan keseluruhan tes.

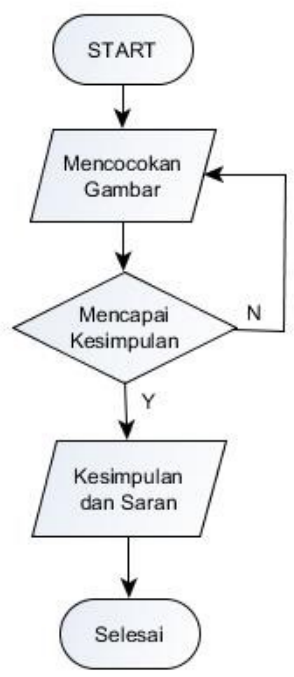

Gambar 16. Flowchart Sistem Pakar Buta Warna

Mengacu pada tes Ishihara terdapat 5 kesimpulan serta tambahan 1 kesimpulan berdasarkan konsultasi bersama pakar yang bersangkutan. Sehingga secara keseluruhan terdapat 6 kesimpulan seperti pada Tabel I.

TABEL I. Kesimpulan PADA Sistem

\begin{tabular}{|c|c|}
\hline Id Kesimpulan & Kesimpulan \\
\hline K1 & $\begin{array}{c}\text { Mengalami Gangguan } \\
\text { Penglihatan }\end{array}$ \\
\hline K2 & Buta Warna Total \\
\hline K3 & Buta Warna Protanopia \\
\hline K4 & Buta Warna Deutanopia \\
\hline K5 & Mata Normal \\
\hline K6 & Inkonsistensi Jawaban \\
\hline
\end{tabular}

Dalam pengujian aplikasi, peneliti menggunakan 3 metode pengujian, pertama adalah pengujian Black Box untuk mengetahui kesesuaian fungsi-fungsi dalam aplikasi dengan rancangan yang telah direncanakan, kedua adalah perhitungan manual yang berguna untuk mengetahui kesesuaian dari tes Ishihara dengan sistem dan yang terakhir adalah pengujian akurasi yang akan berguna untuk mengetahui performa dari sistem yang dibuat.

Dalam pengujian akurasi akan menghitung tingkat keberhasilan sistem dalam menghasilkan jawaban Benar (Sensitivitas) dan jawaban Salah (Spesifitas) dengan rumus sebagai berikut.

1. Sensitivitas

Sensitivitas adalah ukuran keakuratan tes mengenai seberapa besar kemungkinan tes untuk mendeteksi hasil yang positif untuk orang-orang yang memiliki penyakit atau kondisi tertentu, seperti pada Persamaan.1.

$\frac{\sum \text { True Positive }(T P)}{\sum \text { True Positive }(T P)+\sum \text { False Negative }(F N)}$

\section{Spesifitas}

Spesifitas adalah ukuran keakuratan tes mengenai seberapa besar kemungkinan tes untuk mendeteksi hasil yang negatif untuk orang-orang yang memiliki penyakit atau kondisi tertentu, seperti pada Persamaan. 2.

\section{$\sum$ True Negative (TN) \\ $\overline{\sum \text { True Negative }(T N)+\sum \text { False Positif }(F P)}$}

True Positive $(\mathrm{TP})=$ jumlah data yang nilainya seharusnya Benar dan pada sistem dihasilkan Benar.

True Negative $(\mathrm{TN})=$ jumlah data yang nilainya seharusnya Salah dan pada sistem dihasilkan Salah.

False Positive (FP) = jumlah data yang nilainya seharusnya Benar dan pada sistem dihasilkan Salah.

False Negative (FN) = jumlah data yang nilainya seharusnya Salah dan pada sistem dihasilkan Benar.

\section{Hasil Pengujian dan Pembahasan}

Pada bab ini akan membahas mengenai hasil dari penelitian Sistem Pakar Buta Warna Menggunakan Bangun Ruang Berbasis Mobile dengan Sistem Operasi Android berupa implementasi yang dilakukan berdasarkan perancangan yang dijabarkan pada bab sebelumnya. Pembahasan yang akan dijelaskan meliputi implementasi sistem dan hasil pengujian sistem.

\section{A. Implementasi Sistem}

Pada implementasi sistem terdapat beberapa halaman pada sistem yang dibangun antara lain halaman Home, halaman Tes, halaman Kesimpulan lanjutan (termasuk Popup), dan halaman Informasi. Halaman Home terdiri dari sebuah $\operatorname{logo}$ dan 2 tombol yaitu Start yang akan menuju ke halaman Tes dan Information yang akan menuju ke halaman informasi, seperti Gambar 17. 


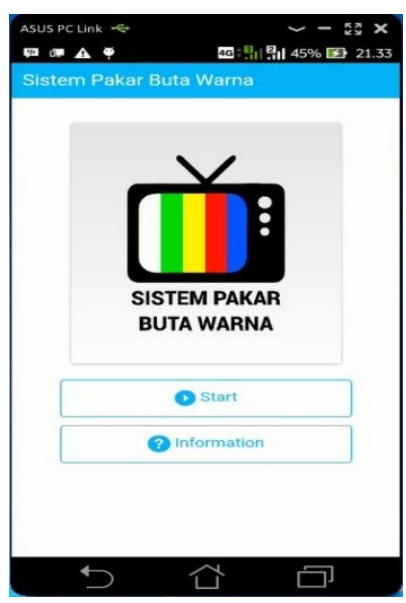

Gambar 17. Interface halaman Home

Pada Halaman Tes terdapat 1 gambar soal yang diacak dari 3 gambar yang ada pada masing-masing tahap, terdapat 4 gambar jawaban yang akan diacak tempat kemunculannya, dan terdapat juga batas waktu pengerjaan sistem yaitu 5 detik, yang terlihat pada Gambar 18. Jika waktu telah habis maka akan tampil Popup yang akan memberitahukan bahwa waktu anda habis dan pada tahap tersebut akan dianggap jawaban salah, seperti pada Gambar 19.

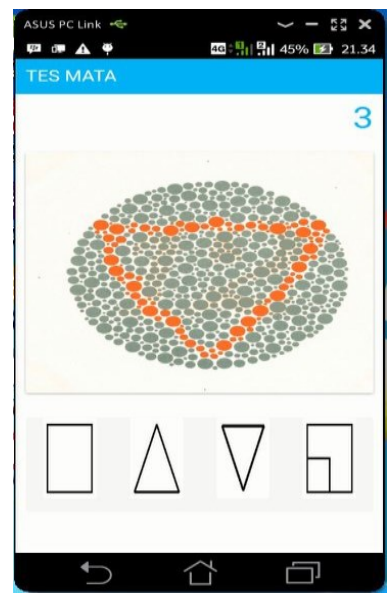

Gambar 18. Interface halaman Tes

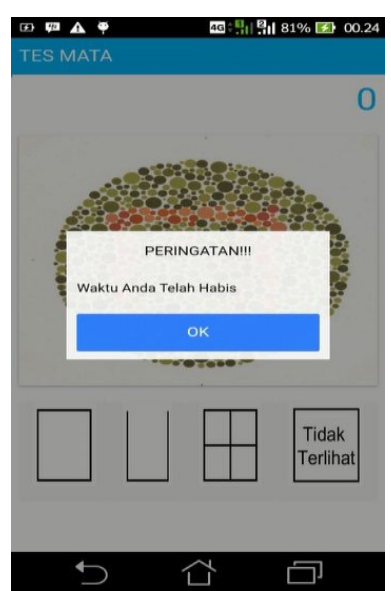

Gambar 19. Interface halaman Tes jika waktu habis

Ketika telah menyelesaikan tes maka akan muncul Popup kesimpulan pada layar yang berisi kesimpulan dari tes yang dilakukan dan pertanyaan apakah anda ingin melihat pemahaman lebih lanjut, jika anda menjawab ok (iya) maka anda akan menuju ke halaman Kesimpulan lebih lanjut dan jika Cancel maka anda akan langsung menuju ke halaman Home, seperti pada Gambar 20. Pada halaman Kesimpulan lebih lanjut terdapat jumlah dari nilai yang telah dijawab sebelumnya, kesimpulan dari tes, penjelasan kesimpulan, saran atas kesimpulan yang didapat serta terdapat 2 tombol yaitu Home yang akan menuju ke halaman Home dan Ulangi yang akan menuju ke halaman Tes untuk melakukan tes kembali, seperti pada Gambar 21.

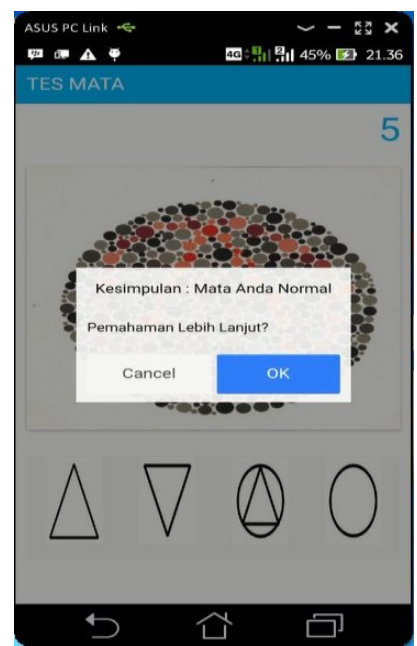

Gambar 20. Interface halaman Tes jika telah menyelesaikan tes 


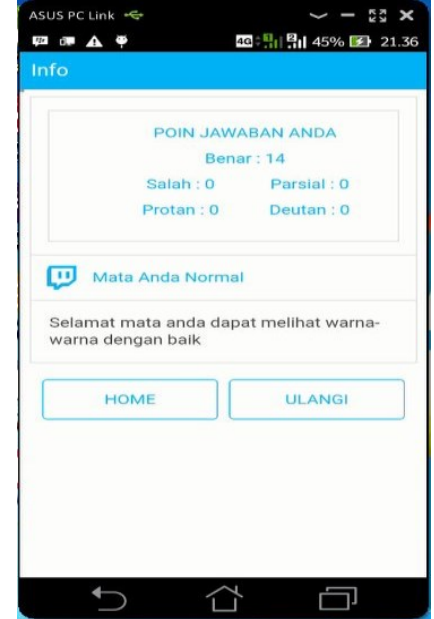

Gambar 21. Interface halaman Kesimpulan lebih lanjut

Pada halaman Informasi terdapat 5 tombol yang akan memberikan informasi-informasi yang penting dalam sistem ini. Tombol tersebut terdiri dari tombol Info Perangkat yang akan menjelaskan perangkat yang digunakan dalam membangun sistem, tombol Info Pemakaian yang memberikan penjelasan mengenai cara pemakaian aplikasi, tombol Info Gambar yang akan menjelaskan gambar soal pada sistem sehingga tidak terjadi kesalahan penafsiran, tombol Info Penyakit yang berisi Daftar kesimpulan beserta penjelasannya dan tombol Kembali ke Home yang akan menuju ke halaman Home, seperti pada Gambar 22.

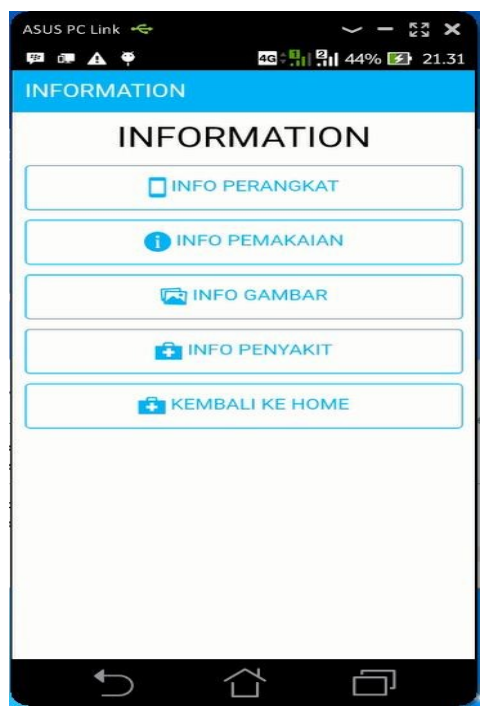

Gambar 22. Interface halaman Kesimpulan

\section{B. Hasil Pengujian}

Pengujian yang pertama adalah pengujian BlackBox, dimana dari hasil pengujian didapatkan bahwa sistem telah berjalan dengan sesuai. Pengujian kedua adalah pengujian manual yang dilakukan untuk menguji kesesuaian tes Ishihara dengan sistem yang dapat dilihat pada Tabel II.

TABEL II. Hasil Tes Perbandingan Ishihara dengan Sistem SECARA MANUAL

\begin{tabular}{|c|c|c|c|}
\hline Subjek & Tes Ishihara & Tes Sistem Pakar & Kesimpulan \\
\hline 1 & Normal & Normal & Sama \\
\hline 2 & Normal & Normal & Sama \\
\hline 3 & Normal & Normal & Sama \\
\hline 4 & Normal & Normal & Sama \\
\hline 5 & Normal & Normal & Sama \\
\hline 6 & Normal & Normal & Sama \\
\hline 7 & Normal & Normal & Sama \\
\hline 8 & Normal & Normal & Sama \\
\hline 9 & Normal & $\begin{array}{c}\text { Buta Warna } \\
\text { Bawaan }\end{array}$ & Berbeda \\
\hline 10 & Normal & $\begin{array}{c}\text { Buta Warna } \\
\text { Bawaan }\end{array}$ & Berbeda \\
\hline 11 & Normal & Normal & Sama \\
\hline 12 & $\begin{array}{c}\text { Buta Warna } \\
\text { Bawaan }\end{array}$ & $\begin{array}{c}\text { Buta Warna } \\
\text { Bawaan }\end{array}$ & Sama \\
\hline 13 & Normal & Normal & Sama \\
\hline 14 & Normal & Normal & Sama \\
\hline 15 & Normal & Normal & Sama \\
\hline 16 & Normal & Normal & Sama \\
\hline Subjek & Tes Ishihara & Tes Sistem Pakar & Kesimpulan \\
\hline 17 & Normal & $\begin{array}{c}\text { Buta Warna } \\
\text { Bawaan }\end{array}$ & Berbeda \\
\hline 18 & Normal & Normal & Sama \\
\hline 19 & Normal & $\begin{array}{c}\text { Buta Warna } \\
\text { Bawaan }\end{array}$ & Berbeda \\
\hline 20 & Normal & Normal & Sama \\
\hline 21 & Normal & $\begin{array}{c}\text { Buta Warna } \\
\text { Bawaan }\end{array}$ & Berbeda \\
\hline 22 & Normal & Normal & Sama \\
\hline 23 & Normal & $\begin{array}{c}\text { Buta Warna } \\
\text { Bawaan }\end{array}$ & Berbeda \\
\hline 24 & Normal & Normal & Sama \\
\hline 25 & Normal & Normal & Sama \\
\hline 26 & Normal & $\begin{array}{c}\text { Buta Warna } \\
\text { Bawaan }\end{array}$ & Berbeda \\
\hline 27 & Normal & Normal & Sama \\
\hline 28 & Normal & Normal & Sama \\
\hline 29 & Normal & Normal & Sama \\
\hline
\end{tabular}




\begin{tabular}{|c|c|c|c|}
\hline 30 & Normal & Normal & Sama \\
\hline 31 & Normal & Normal & Sama \\
\hline 32 & Normal & $\begin{array}{c}\text { Buta Warna } \\
\text { Bawaan }\end{array}$ & Berbeda \\
\hline 33 & Normal & Normal & Sama \\
\hline 34 & $\begin{array}{c}\text { Buta Warna } \\
\text { Bawaan }\end{array}$ & $\begin{array}{c}\text { Buta Warna } \\
\text { Bawaan }\end{array}$ & Sama \\
\hline 35 & Normal & Normal & Sama \\
\hline 36 & $\begin{array}{c}\text { Buta Warna } \\
\text { Bawaan }\end{array}$ & $\begin{array}{c}\text { Buta Warna } \\
\text { Bawaan }\end{array}$ & Sama \\
\hline 37 & $\begin{array}{c}\text { Buta Warna } \\
\text { Bawaan }\end{array}$ & $\begin{array}{c}\text { Buta Warna } \\
\text { Bawaan }\end{array}$ & Sama \\
\hline 38 & Normal & Normal & Sama \\
\hline 39 & Normal & Normal & Sama \\
\hline 40 & Normal & Normal & Sama \\
\hline \multicolumn{3}{|c|}{ Jumlah Kesimpulan Yang Sama } & 32 \\
\hline
\end{tabular}

Berdasarkan Tabel I terdapat 8 subjek yang memiliki jawaban berbeda antara Ishihara dengan sistem, berdasarkan pengamatan peneliti maka dilakukan pengujian kembali dengan menggunakan waktu yang sebelumnya hanya 5 detik menjadi 15 detik dan diujikan kepada subjek yang memiliki jawaban yang tidak sama. Hasilnya didapat keseluruhan subjek menjawab sama, sehingga dapat kita simpulkan bahwa kesesuaian Tes Ishihara dengan Sistem yang dibangun dengan menggunakan batas waktu 5 detik untuk setiap tahap mencapai $80 \%$ dan dengan menggunakan batas waktu 15 etik untuk setiap tahap mencapai $100 \%$.

Pengujian ketiga adalah pengujian plat Ishihara dengan Plat Perubahan yang telah dibuat oleh peneliti kepada 4 subjek penderita buta warna parsial, seperti pada Tabel III. Pada pengujian ini akan melihat apakah plat yang diubah sudah sesuai dengan plat Ishihara sebagai acuan.

TABEL III. Hasil Perhitungan Plat Secara Manual pada SUBJEK PENDERITA BUTA WARNA PARSIAL

\begin{tabular}{|c|c|c|c|c|c|c|}
\hline No & Ishihara & Perubahan & S1 & S2 & S3 & S4 \\
\hline 1 & \multirow{3}{*}{ Plat 1} & G01 & & & & \\
\hline 2 & & G02 & & & & \\
\hline 3 & & G03 & & & & \\
\hline 4 & \multirow{3}{*}{ Plat 2} & G04 & $\mathrm{x}$ & & & $\mathrm{x}$ \\
\hline 5 & & G05 & $\mathrm{x}$ & & & $\mathrm{x}$ \\
\hline 6 & & G06 & $\mathrm{x}$ & & & \\
\hline
\end{tabular}

\begin{tabular}{|c|c|c|c|c|c|c|}
\hline 7 & & G07 & & & $\mathrm{x}$ & $\mathrm{x}$ \\
\hline 8 & Plat 3 & G08 & & & $\mathrm{x}$ & $\mathrm{x}$ \\
\hline 9 & & G09 & $\mathrm{x}$ & & $\mathrm{x}$ & $\mathrm{x}$ \\
\hline 10 & & G10 & $\mathrm{x}$ & & & \\
\hline 11 & Plat 4 & G11 & $\mathrm{x}$ & & & \\
\hline 12 & & G12 & $\mathrm{x}$ & & & \\
\hline 13 & & G13 & $\mathrm{x}$ & $\mathrm{x}$ & $\mathrm{x}$ & \\
\hline 14 & Plat 5 & G14 & $\mathrm{x}$ & $\mathrm{x}$ & $\mathrm{x}$ & \\
\hline 15 & & G15 & $\mathrm{x}$ & $\mathrm{x}$ & $\mathrm{x}$ & \\
\hline 16 & & G16 & & $\mathrm{x}$ & $\mathrm{x}$ & $\mathrm{x}$ \\
\hline 17 & Plat 6 & G17 & $\mathrm{x}$ & & & \\
\hline 18 & & G18 & & $\mathrm{x}$ & $\mathrm{x}$ & $\mathrm{x}$ \\
\hline 19 & & G19 & $\mathrm{x}$ & & & $\mathrm{x}$ \\
\hline 20 & Plat 7 & G20 & $\mathrm{x}$ & & & $\mathrm{x}$ \\
\hline 21 & & $\mathrm{G} 21$ & & & & $\mathrm{x}$ \\
\hline No & Ishihara & Perubahan & S1 & S2 & S3 & $\mathrm{S} 4$ \\
\hline 22 & & $\mathrm{G} 22$ & & & & \\
\hline 23 & Plat 8 & $\mathrm{G} 23$ & & & & \\
\hline 24 & & G24 & $\mathrm{X}$ & & & \\
\hline 25 & Plat 9 & G25 & \multicolumn{4}{|c|}{ Tidak Di uji } \\
\hline 26 & \multirow{3}{*}{ Plat 10} & G26 & & & & \\
\hline 27 & & G27 & & & & \\
\hline 28 & & G28 & & & & \\
\hline 29 & \multirow{3}{*}{ Plat 11} & G29 & $\mathrm{X}$ & & & \\
\hline 30 & & G30 & & & & \\
\hline 31 & & G31 & & & & \\
\hline 32 & \multirow{3}{*}{ Plat 12} & G32 & $\mathrm{X}$ & $\mathrm{x}$ & & \\
\hline 33 & & G33 & & $\mathrm{x}$ & & \\
\hline 34 & & G34 & $\mathrm{X}$ & $\mathrm{x}$ & & \\
\hline 35 & Plat 13 & G35 & & $\mathrm{x}$ & & \\
\hline
\end{tabular}




\begin{tabular}{|r|c|c|c|c|c|c|}
\hline 36 & & $\mathrm{G} 36$ & & $\mathrm{x}$ & & \\
\cline { 1 - 5 } 37 & & $\mathrm{G} 37$ & & $\mathrm{x}$ & & \\
\hline 38 & \multirow{5}{*}{ Plat 14} & $\mathrm{G} 38$ & & & & \\
\cline { 1 - 5 } & $\mathrm{G} 39$ & & $\mathrm{x}$ & & \\
\hline & & $\mathrm{G} 40$ & & $\mathrm{x}$ & & \\
\hline & & & & & & \\
\hline
\end{tabular}

Keterangan :

- S1-S4 adalah subjek penelitian yang berjumlah 4 orang.

- Nilai x adalah jawaban yang tidak sesuai antara Plat Ishihara dengan Plat Perubahan.

- G01-G40 adalah nama plat perubahan. (Dapat dilihat pada lampiran).

Berdasarkan hasil pengujian pada Tabel 2 menunjukan bahwa terdapat beberapa plat yang bermasalah dan yang paling gagal berjumlah 6 plat yaitu Plat G09 (Ishihara Plat 3), G13, G14, G15 (Ishihara Plat 5), G16 dan G18 (Ishihara Plat 6). Pada plat gagal tersebut dari 4 subjek 3 diantaranya menjawab tidak sesuai sehingga plat tersebut dapat dikatakan gagal, sehingga presentase jumlah plat yang gagal adalah $15 \%$ yang didapat dari jumlag plat gagal 6 dibagi jumlah keseluruhan plat yaitu 40. Kegagalan tersebut dapat terjadi akibat kesalahan dalam pengubahan plat dimana gradasi warna pada plat gagal sangat kontras sehingga subjek yang tidak dapat melihat angka malah dapat melihat bangun ruang yang dibuat. Pengujian plat juga dilakukan terhadap subjek dengan mata normal dengan jumlah yang sama yaitu 4 subjek, dengan hasil keseluruhan menjawab BB (Benar pada Ishihara dan Benar pada plat Perubahan) sehingga dapat dikatakan plat yang dibangun telah layak dalam penggunaannya.

Pengujian yang terakhir adalah pengujian akurasi yang Bedasarkan Tabel 1 dimana tes dilakukan dengan batas waktu 5 detik, dapat dihasilkan sebuah kesimpulan akurasi yaitu sensitivitas dan spesifitas yang akan menunjukan persentase kemungkinan sistem menghasilkan jawab yang condong ke benar atau condong ke salah. Berikut adalah data-data tes pengujian sistem dengan batas waktu 5 detik yang telah dikelompokan,

- True Positive $(\mathrm{TP})=$ jumlah data yang nilainya seharusnya Benar dan pada sistem dihasilkan Benar berjumlah 28 .

- True Negative $(\mathrm{TN})=$ jumlah data yang nilainya seharusnya Salah dan pada sistem dihasilkan Salah berjumlah 4.

- False Positive (FP) = jumlah data yang nilainya seharusnya Benar dan pada sistem dihasilkan Salah berjumlah 8 .

- False Negative $(F N)=$ jumlah data yang nilainya seharusnya Salah dan pada sistem dihasilkan Benar berjumlah 0 .

\section{B.1. Sensitivitas}

Sensitivitas adalah perhitungan yang menyatakan persentase kesimpulan dari sistem menghasilkan nilai positif atau tingkat kebenarannya tinggi. Dapat diartikan sebagai nilai ketepatan dalam memprediksi jawaban benar. Sensitivitas dengan waktu 5 detik,

$$
\begin{aligned}
& =\frac{\sum \text { True Positive }(T P)}{\sum \text { True Positive }(T P)+\sum \text { False Negative (FN) }} \\
& =\frac{28}{28+0}=1
\end{aligned}
$$

Berdasarkan hasil pada perhitungan diatas, persentase sensitivitas sistem dengan batas waktu 5 detik adalah $1 \mathrm{x}$ $100 \%=100 \%$.

\section{B.2. Spesifitas}

Spesifitas adalah perhitungan yang menyatakan persentase kesimpulan dari sistem menghasilkan nilai negatif atau tingkat kesalahannya tinggi. Dapat diartikan sebagai nilai ketepatan dalam memprediksi jawaban salah. Spesifitas dengan waktu 5 detik,

$$
\begin{aligned}
& =\frac{\sum \text { True Negative }(T N)}{\sum \text { True Negative }(T N)+\sum \text { False Positif (FP) }} \\
& =\frac{4}{4+8}=0,34
\end{aligned}
$$

Berdasarkan hasil pada perhitungan diatas, persentase spesifitas sistem dengan batas waktu 5 detik adalah $0,34 \mathrm{x}$ $100 \%=34 \%$.

Pada tes dengan batas waktu 15 detik memiliki data hasil yang hampir sama dengan data sebelumnya namun berbeda pada jumlah False Positive (FP) yaitu berubah menjadi 0 . Sehingga nilai pada spesifitasnya akan berubah dan sensitivitasnya tetap sama, seperti rumus berikut

1. Sensitivitas dengan waktu 15 detik

$$
\begin{aligned}
& =\frac{\sum \text { True Positive }(T P)}{\sum \text { True Positive }(T P)+\sum \text { False Negative }(F N)} \\
& =\frac{28}{28+0}=1
\end{aligned}
$$

Berdasarkan hasil pada perhitungan diatas, persentase sensitivitas sistem dengan batas waktu 15 detik adalah $1 \mathrm{x}$ $100 \%=100 \%$.

\section{Spesifitas pada waktu 15 detik}

$$
\begin{aligned}
& =\frac{\sum \text { True Negative }(T N)}{\sum \text { True Negative }(T N)+\sum \text { False Positif }(F P)} \\
& =\frac{4}{4+0}=1
\end{aligned}
$$

Berdasarkan hasil pada perhitungan diatas, persentase spesifitas sistem dengan batas waktu 5 detik adalah $1 \mathrm{x}$ $100 \%=100 \%$.

Berdasarkan hasil perhitungan diatas dapat disimpulkan sistem pakar buta warna dengan menggunakan batas waktu 5 detik memiliki kesimpulan yang akan menghasilkan jawaban Salah sebesar 66\%, namun jika batas waktu dinaikan menjadi 15 detik maka sistem akan menjadi 100\% karena seluruh jawaban sesuai antara tes Ishihara dan sistem. 


\section{KESIMPUlan DAN SARAN}

Kesimpulan yang didapatkan dari pembahasan dan penelitian Sistem Pakar Buta Warna Menggunakan Bangun Ruang untuk perangkat Mobile dengan Sistem Operasi Android, adalah:

1. Pembuatan Sistem Pakar Buta Warna ini sudah memiliki kesesuaian alur penggambilan keputusan dengan metode Ishihara.

2. Sistem ini menggunakan plat perubahan yang menggunakan gambar bangun ruang dengan akurasi keberhasilan pada batas waktu 5 detik sebesar $80 \%$ dan 15 detik $100 \%$.

3. Plat perubahan dengan bangun ruang dapat mendeteksi subjek yang diduga menderita buta warna yang tidak dapat dideteksi oleh plat ishihara.

4. Dari hasil pengujian black box menunjukkan bahwa seluruh fungsi telah berjalan sesuai dengan sistem yang diusulkan.

5. Berdasarkan hasil dari setiap jawaban tes pada subjek penderita buta warna parsial presentase kesesuaian subjek menjawab Benar pada plat 0,58, menjawab Salah sekitar 0,72, menjawab Parsial sekitar 0,33, menjawab Deutanopia sekitar 0,90 dan untuk Protanopia tidak ada, sedangkan hasil tes pada subjek dengan mata normal presentase kesesuaian subjek menjawab Benar pada plat mencapai 100\%.

6. Berdasarkan hasil uji akurasi pada data waktu 5 detik didapatkan hasil sensitivitas dari sistem 100\% dan spesifitas dari sistem $34 \%$, sedangkan pada waktu 15 detik didapatkan spesifitas dari sistem menjadi $100 \%$.

7. Presentase jumlah plat yang gagal adalah $15 \%$ yaitu 6 plat gagal dari 40 plat yang dirancang, yang disebabkan kesalahan gradasi warna pada plat.

Saran untuk pengembangan lebih lanjut pada aplikasi adalah dapat dikembangkan pada framework lainnya , dapat menggubah plat dengan mencoba gambar-gambar lainnya, penggunaan database offline karena pada sistem masih berupa array dan peneliti selanjutnya dapat memperbaiki plat yang gagal atau menggantinya dengan plat baru yang lebih sesuai dengan plat Ishihara dan mengikutsertakan mayarakat penderita buta warna dalam mengubah plat, sehingga mendapat maukan mengenai plat yang dibangun serta menambahkan pengujian kepada subjek penderita buta warna total.

\section{DAFTAR PUSTAKA}

[1] N. Karina, Mengenal Lebih Dekat Buta Warna. 2007.

[2] S. Poret, R.D. Jony, dan S. Gregory, "Image Processing for Colour Blindness Correction. Sciene and Technology dor Humanity," IEEE Toronto International Conference, Toronto, Canada, 2009.

[3] A. Yanuarita, Tes Buta Warna. Yogyakarta: Rona Publishing, 2012.

[4] S. Kusumadewi, Artificial Intelligence (Teknik dan Aplikasi). Yogyakarta: Graha Ilmu, 2003.

[5] P. Prabawati, Sistem Pakar Diagnosa Buta Warna Berbasis Android. Semarang: Fakultas Teknik, Universitas Negeri Semarang, 2015.

[6] H. Murti, dan R.C.N. Santi, Rina, Aplikasi Pendiagnosa Kebutaan Warna dengan Menggunakan Pemrograman Borland Delphi. Semarang: Fakultas Teknologi Informasi, Universitas Stikubank Semarang, 2011.

[7] Hartono dan R.C. Naibaho, Sistem Pakar Diagnosa Penyakit Buta Warna Berbasis Android. STMIK IBBI, 2013.

[8] --------, APJII, Buletin Asosiasi Penyelenggara Jasa Internet Indonesia, Edisi November, Jakarta, 2016 